\title{
Bringing the margins into the middle - reflections on Racism, Class and the Racialized Outsider
}

\section{A Seesaw of History}

Books like this don't come around very often. With Racism, Class and the Racialized Outsider, Virdee (2014) seeks to enrich our social theories with detailed political histories, and in so doing presents a corrective to each. Historically, the book makes visible the 'racialized minorities in socialist movements who played an instrumental role in trying to align struggles against racism with those against class exploitation' (Virdee, 2014: 164). Theoretically, it reads off this activity that prevailing accounts of race and racialization have overlooked the ways in which the 'racialized outsider' can act as 'a leavening agent nourishing the struggles of all, informed by their unique perspectives on society' (ibid). In its historical mode the book might rest in the company of a handful of texts, though none is a perfect comparator. I have in mind James Walvin's trio: (1972) The Black Presence: A Documentary History of the Negro in England, 1555-1860; (1973) Black and White: The Negro and English Society (1555-1945), and Making the Black Atlantic: Britain and the African Diaspora (2000). Perhaps it also shares something in common with classics like Peter Fryer's (1984) Staying Power: A History of Black People in Britain and C.L.R. James' (1991) The Black Jacobins, but tackles core arguments in others, not least omissions in E. P. Thompson's (1963) The Making of the English Working Class, and Linda Colley's (1996) Britons. I find it interesting that in the main it is easier to locate Virdee's text alongside monographs in history than monographs in social theory. Perhaps Robert Miles' (1982) Racism and Migrant Labour is an exception to this, as well as the early work on racism and the welfare state by Mike Cole, but kith and kin in the literature on race and racialization nonetheless come in shorter forms. One especially thinks of Sivanandan's (1982) collection of papers in A Different Hunger and Stuart Hall's (1980) essay on 'Race, Articulation and Structured Dominance'.

Knowing these texts sufficiently well, I am especially struck by the nature of the historical seesaw of inclusion and exclusion throughout Virdee's addition. It's a dramatic and compelling account, in so far as '[e]ach time the boundary of the nation was extended to encompass ever more members of the working class, it was accompanied and legitimised through the further racialization of nationalism that prevented another more recently arrived group from being included' (Virdee, 2014: 5). Clearly therefore there is a lot we could discuss here and so I would like to use the limited space to make a couple of modest and tentative observations on the following issues.

\section{What's in a sociological concept?}

The notion of 'Racialised Outsider' appears to bring into a focus a number of issues. Firstly, the process of race-making - or becoming 'racialised' - which, in Virdee's account as others, notes the move from an idea of race resembling 'lineage' to something which 
'assumed an additional sense that seemed, initially, tighter and more scientific... a finite number of basic human types, each embodying a package of fixed and mental traits' (Biddis, 1979: 11). The process is of course key and well established, but in Virdee's reading it does not take a linear route. 'Race', instead, 'was constitutive in the making, unmaking and remaking of the working class in England across two centuries' (ibid. p. 8). As such, and especially in the organisation of social and political life, 'there were historical moments when the working class supressed such expressions of racism, and on occasion, actively rejected it' (Virdee, 2014: 5-6). Such is the nature of racialization: a juddering movement of rejection of one group and the incorporation of another (or later indeed the same group), and which can be quite consistent with intellectual and popular logics of racializing. Secondly, the 'outsider' part adds something distinct to the prevailing tradition of 'outsiders' as in the American interactionist scholarship, the provenance of which is part of the folklore of sociology, through the work of Howard Becker and colleagues in the Chicago school in particular. This was very much taken up in labelling theories and what we might think of as the study of crime and deviance (and which can spin out and across social theory through the idea of 'significant others' and so forth). I don't see Virdee appealing to this. Nor do I read him as reaching for a very different fashion of thinking about the outsider as the 'Other'. While this is getting nearer to how I understand Virdee's concept, the current home of the 'Other' is post-colonial inquiry, and Virdee is adamant that in his case such framings 'must be rejected because they unnecessarily flatten British history, eliminating the bitter class conflicts that erupted and structured and structured class in this period' (2014: 60). The challenge for Virdee instead is to develop a sociological concept of 'Racialised Outsider', one that is theoretically transferable beyond the micro encounter between different actors, and is especially able to incorporate social structure, but is historically meaningful and sensitive to resistance. In his discussion of the Irish Catholics he clarifies how:

The term 'racialized outsider' is employed to denote how this groups prior experience of subjugation and racialization as a people at the hands of the British elite helped inform their relative lack of enthusiasm for, and commitment to, the dominant politics and representations of the British nation once in Britain. After all, 'their' nation was under the iron heel of the British state, they were castigated as Catholics and increasingly as members of an inferior Catholic race. And this detachment from the dominant ideology provided then with a unique perspective, an alternative lens' (ibid. 24).

In my own work I have observed similar dynamics in Du Bois' notion of 'gifted second sight', an ontological perspective and sense of political clairvoyance, summed up his is statement that ' $W e$ in America can see America as it cannot see itself' (Du Bois, quoted in Meer, 2010). Virdee might equally relate his reading to Lukacs, but it is interesting that Virdee does not want to be contained by a paradoxically parochial Global north-south conception of centre and periphery, and highlights the internal plurality of the 'racialized outsider' through the inclusion of the Irish Catholic presence. In so doing I think this adds something new and important to the whiteness literatures in particular, and especially the ambiguous place that Irish racialized outsiders have occupied (Hickman, 1998). ${ }^{\mathrm{i}}$ This is at least one of ways I indicated that the book cuts against the grain of Colley's (1996) influential 
account, which in not being attentive to 'Ireland's position as a colony of Britain - not thousands of miles away but in its own backyard - fails to grasp the political significance of Irish Catholic migration to Britain' (Virdee, 2014: 23). But the Irish are not the only part of Virdee's equation. The political content and context of antisemitism in British Socialism is meticulously catalogued too. For when the nation is reimagined and the racialized Irish become part of the working class, Virdee shows how this occurs at the expense of consolidating another 'modality of racism' - namely antisemitism. Centring on political mobilisations around the 1905 Aliens Act, Virdee sheds light on how 'many socialist nationalists were complicit in this surge in anti-Semitism that led to the introduction of such racist legislation. Whether it was because the Jews were of an 'alien race' or the bearers of culture that they deemed was unassimilable the socialist nationalist's refusal to integrate the Jewish worker into broader class struggles of the new unionism was a profound failing' (ibid. $54)$.

\section{The race-class nexus}

Taken as a whole this book is quite consistent with Virdee's wider intellectual investment that has seen him 'navigate between the Scylla of reducing race to class (as Marxists were, and are prone to do) and the Charybdis of studying race in isolation from class (as so many in sociology continue to do)' (Virdee, quoted in Meer and Nayak, 2013: 6). One way of addressing - in some respects overcoming - the race-class binary is to recast it as a nexus, an interpellation even, such that 'race became "the modality in which class [was] lived, the medium through which class relations [were] experienced the form in which it [was] appropriated and 'fought through" (Hall, 1980: 341)' (Virdee, 2014: 163). To a large extent, however, class dynamics have been overlooked in much of the discussion of whiteness in particular, something that has attributed a conscious or unwitting white dominance; a move that under-recognises how '[t]he economic and psychological wages of whiteness may be more meagre (and thus more precious) the lower down the social hierarchy the white subject is located' (Garner, 2006: 262). In several respects Virdee shows this to be the case, and especially how at important junctures the white working class in England 'remained relatively free of contamination by the ideology of white-supremacy' (Virdee, 2014: 25).

These debates have moved on but not necessarily forward. Once exception is Nayak's fieldwork (2003) in contemporary post-industrial settings which explores how whiteness intersects with class and masculinities, and so is negotiated in ways that take on 'multiple and contingent' meanings (ibid. 319). This is especially evident in terms of how 'whiteness is not simply constituted in relation to blackness as previous race studies expertly show, but is also fashioned through and against other versions of whiteness' (ibid.: 320, emphasis added). What this emphasises is that whiteness needs to be registered as more than supremacy, privilege and capital; it also needs to be understood as a class identity that can be negotiated, and so is much more than an outcome of racial dualism. In Virdee's account it is less the everyday but instead the seismic events during the 'heroic age of the proletariat' against 
which such a race-class nexus has historically been forged and broken. The defeat of Chartism is a recurring theme. Possibly sharing something with Lorimer's (1978) reading that racism became an entrenched feature of this fallout, especially in so far as it broke the link between 'oppression abroad with exploitation at home' that was previously 'consistently made and sustained by Irish and English radicals and gave the Chartists an outlook and political complexion that regularly transcended the traditional boundaries of British nationalism (Virdee, 2014: 29). He continues:

\begin{abstract}
With the defeat of Chartism, 'the "heroic age of the proletariat' had passed'. (p. 34). [I]n the moment of political defeat, groups of workers turned in on themselves thereby unmaking themselves as a class. [...] In mid-Victorian England, the traditionally religious underpinnings of British nationalism were over-determined by a form of scientific racism that re-imagined Britain as an Anglo-Saxon Protestant nation in opposition to Catholics of the Celtic race on British soil.' (ibid.). [...] An understanding of 'racial' difference embedded itself in the cultural and political life of the working class in England. (p. 35).
\end{abstract}

\title{
A timely intervention
}

As I have already indicated, Virdee's text makes a welcome intervention. Our politicians appear to be bleaching national narratives partly out of contingency (to correspond to election cycles and short term political advantage) though no less than for reasons of ideology too. On each occasion the available counter-histories appear fewer, or certainly less audible, and popular historians and other ideologues often collude in the elevation of positive myths and - no doubt in their view - noble lies. And so Virdee's book foregrounds a question: at the levels of public discourse and policy, how to bring these overlooked histories into current debates. They bear an obvious implication for the kinds of nationalism advocated by David Goodhart (2013) - for whom ethnic diversity is a novelty and historically extrinsic to the body politic - and other 'Left' figures who feel ethnic and racial minorities have taken something from them. The positive reception of such accounts might be taken as confirmation of a pervasive historical illiteracy.

Part of the answer to this predicament surely rests in engaged scholarship on race. I have complained elsewhere about the 'laundering of race in England's sociology departments (and its near complete absence in Wales and Scotland, with the important exception of universities across Glasgow)' (Meer, 2014: 1794), and so I should not miss the opportunity to do so again here. Why is there less institutional investment in race by the white men and women who govern our university departments, schools and faculties? And at what cost? How could it come to pass that in the long debate about Scottish Independence, race and Empire went unmentioned? Scotland of course has a long and interesting encounter with 'Racialialized Outsiders', and yet as Tom Devine has noted: 'between 1936 and 2003, there was no academic analysis of Scotland's role in the British Empire' (quoted in Goursoyanni 2012, 61). Yet we know the Scottish story, just as the English one, is 'Bursting with Skeletons' (Marquand 2009), and that throughout various cycles of British expansionism and colonial 
settlement, the sons and daughters of Scotland have made up its military and civilian ranks in copious numbers (Stenhouse 2004). Devine (2003: 251) has set himself the task of elaborating how in the most profitable parts of the East Indian Trading Company, roughly half of the accountants and officer cadets were Scottish. In the words of the third Earl of Rosebery, this relationship 'Scotticised India and Orientalised Scotland' (quoted in Devine 2003, 126). Indeed, from the middle of the nineteenth century, the British Raj system was created under a Scottish governor (General James Dalhousie), while elsewhere the Scot Charles James Napier effectively annexed the Sind province (a large part of modern Pakistan). Hence, by the mid-nineteenth century, when one in ten of the British population was Scottish, one third to a quarter of the civil service elite grade of the East India Company was Scottish.

My point is that this was not one-way traffic - the empire came often and long before Windrush docked in Tilbury - yet this brief summary is probably more than most Scottish undergraduates in the Social Sciences students will receive on their first two years of a sociology program in Scotland. And this is a sad state of affairs, and which - though focusing mainly on England - Virdee's contribution can help reverse. On that note I leave the final words to the author, to remind us of the virtue of reading history against the grain: 'By demonstrating the multi-ethnic character of the working class in England from the moment of its inception, racialized minorities can no longer be reduced to margins of the historical account of its making and unmaking' (Virdee, 2014: 7-8).

\section{References}

Biddis, M. (ed.) (1979) Images of Race. New York: Holmes \& Meier.

Colley, L. (1996) Britons. London: Vintage.

Devine, T. (2003) Scotland's Empire. Allen Lane

Fryer. P. (1984) Staying Power: A History of Black People in Britain. London: Pluto.

Garner, S. (2011) Racisms. London: Sage.

Goodhart, D. (2013) The British Dream. Atlantic.

Goursoyanni, P. (2012) 'An Historical Moment’, Holyrood, Summer, pp. 61-64.

Hickman, M. (1998) 'Reconstructing Deconstructing 'Race', Ethnic and racial Studies, 21 (2), 288-307.

Hall, S. (1980) essay on 'Race, Articulation and Structured Dominance', in: UNESCO (ed) Sociological Theories: race and colonialism. Paris: UNESCO

James, C.L.R. (1991) The Black Jacobins. The Black Jacobins. London: Allison and Busby. 
Lorimer D (1978) Colour Class and the Victorians: English Attitudes to the Negro in the Mid-Nineteenth Century. Leicester: Leicester University Press

Marquand, D. (2009) ''Bursting with Skeletons' - Britishness after Empire', in: A. Gamble and T. Wright (eds) Britishness Perspectives on the British Question. Wiley-Blackwell.

Meer, N. (2010) Citizenship, Identity \& the Politics of Multiculturalism. Basingstoke: Palgrave.

----(2014) 'Revisiting the crossroads: returning to The Empire Strikes Back', Ethnic and Racial Studies Review, 37 (10), 1793-1801

Meer, N. and Nayak, A. (2013) 'Race, racism and contemporary sociology', Sociology. 0038038513501943. p. 1-18

Miles, R. (1982) Racism and Migrant Labour. London: Routldge.

Mycock, A. (2010) 'British Citizenship and the Legacy of Empires', Parliamentary Affairs 63

(2): $339-355$.

Nayak, A. (2003a) "Ivory lives": economic restructuring and the making of whiteness in a post-industrial youth community', European Journal of Cultural Studies, 6 (3), 305-25.

Sivanandan, A. (1982) A Different Hunger. London: Pluto.

Stenhouse, D. (2004) On the Make: How the Scots took over London. Edinburgh: EUP.

Thompson, E. P. (1963) The Making of the English Working Class. London: Penguin.

Walvin, J. (1972) The Black Presence: A Documentary History of the Negro in England, 1555-1860. Orbach \& Chambers Ltd.

----(1973) Black and White: The Negro and English Society (1555-1945). Allen Lane.

----(2000) Making the Black Atlantic: Britain and the African Diaspora. Leicester University Press.

NASAR MEER is a Reader in the Faculty of Humanities and Social Sciences, University of Strathclyde, and a Royal Society of Edinburgh Research Fellow (2014-2019).

ADDRESS: Faculty of Humanities and Social Sciences, University of Strathclyde, 16 Richmond Street, Glasgow G1 1XQ, Scotland.

Email: www.nasarmeer.com

\footnotetext{
'From the perspective of racialized Muslims today, Briton's of an Irish Catholic background are of course part of the white club.
} 